This is a self-archived version of an original article. This version may differ from the original in pagination and typographic details.

Author(s): Čeginskas, Viktorija L. A.; Kaasik-Krogerus, Sigrid

Title: Politics of solidarity in the context of European heritage : The cases of the European Solidarity Centre and Hambach Castle

Year: 2020

Version: Accepted version (Final draft)

Copyright: (c) The Authors, 2019

Rights: In Copyright

Rights url: http://rightsstatements.org/page/InC/1.0/?language=en

Please cite the original version:

Čeginskas, V. L. A., \& Kaasik-Krogerus, S. (2020). Politics of solidarity in the context of European heritage : The cases of the European Solidarity Centre and Hambach Castle. International Journal of Heritage Studies, 26(10), 998-1012. https://doi.org/10.1080/13527258.2019.1663235 


\title{
Politics of Solidarity in the context of European Heritage. The cases of the European Solidarity Center and Hambach Castle
}

\author{
Viktorija Čeginskas $^{\text {a* }}$ and Sigrid Kaasik-Krogerus ${ }^{\mathrm{b}}$ \\ ${ }^{a}$ Department for Music, Art and Culture Studies, University of Jyväskylä, Jyväskylä, \\ Finland ${ }^{b}$ Department for Music, Art and Culture Studies, University of Jyväskylä, \\ Jyväskylä, Finland
}

*Viktorija L.A. Čeginskas; E-mail: viktorija.ceginskas@jyu.fi; Department of Music, Art and Culture Studies; P.O. Box 35; 40014 University of Jyväskylä; Finland

Viktorija L.A. Čeginskas (PhD; ORCID: 0000-0002-5794-9503) currently works as a postdoctoral researcher in the research project 'Legitimation of European Cultural Heritage and the Dynamics of Identity Politics in the EU' (EUROHERIT, ERC Starting Grant 2015-2020) at the University of Jyväskylä, Finland. Čeginskas has a PhD in Cultural Heritage Studies from the University of Turku, Finland and a MA in contemporary history, East-European history and European Ethnology from Christian-Albrechts-Universität, Kiel, Germany. Her research interests include narratives of belonging, identity politics, transnational mobility and heritage studies in a European context.

Sigrid Kaasik-Krogerus (DSocSc; ORCID: 0000-0002-6424-5520) is a post-doctoral researcher at the Department of Music, Art and Culture Studies, University of Jyväskylä, Finland. She currently works in the research project Legitimation of European Cultural Heritage and the Dynamics of Identity Politics in the EU (EUROHERIT), funded by the European Research Council. From 2015-2018 she was a member of the Jean Monnet Module East within Europe funded by the Erasmus + at the Aleksanteri Institute, University of Helsinki. Kaasik-Krogerus specialises in media and communication, identity politics, heritage, and European studies in the context of the EU and especially Central and East European countries.

Total word count (without the title page): 8385 The number of figures included: 4

Pictures only to be included if without any additional costs and charges for the authors. 


\title{
Politics of solidarity in the context of the European Heritage. The cases of the European Solidarity Center and Hambach Castle
}

\begin{abstract}
This article explores the politics of solidarity in the framework of constructing a common cultural heritage of the European Union. The politics of solidarity stems from the notion of solidarity embedded to European heritage. We use critical heritage studies as a theoretical approach that understands heritage as an inherently dissonant social construct, produced by various actors according to political, economic and social interests. The study analyses empirical data from the European Heritage Label (EHL), a flagship heritage action of the EU that communicates shared values and a sense of identification to European citizens. Our empirical data includes ethnographic observation as well as interviews with experts and visitors at two EHL sites, the Hambach Castle (Germany) and the European Solidarity Centre (Poland). The sites specifically mediate the notion of solidarity to the visitors as a bottom-up process that has a strong potential to produce societal change. Our analysis shows how the EHL conducts twofold politics of solidarity. First, by designating the label to this kind of site, solidarity is embedded into European heritage. Second, by heritagising solidarity, the EHL endeavours to evoke a sense of solidarity among contemporary Europeans.
\end{abstract}

Keywords: politics of solidarity, critical heritage studies, communication, transformation, EU, European Heritage Label

\section{Introduction}

In the context of the current 'crises' in the European Union (EU), solidarity has been one of the key themes in the EU political arena and related academic research. These 'crises' include the economic recession, the 'Euro crisis', as well as the so-called 'refugee crisis', which refers to the accelerated increase in the number of people seeking refuge in Europe. Additionally, the 'crisis' agenda of the EU involves the search for a common position on the war in Ukraine and for coping with rising populist and EU-critical political forces in the member states. A topical issue is also the uncertain future relations with the UK as a result of the impending 'no deal-Brexit'-issue, which is imposed by the UK populist parties and politicians on the EU member states. With its persistent presence in 
the EU law (Treaty Establishing a Constitution for Europe 2004; see also Ross 2010; Góra 2018), solidarity, and a lack of it, is therefore a prominent part of discussing the wider impact of the financial crisis, the rise of EU-critical forces and in connection with issues of immigration (e.g. Bell 2010; Karageorgiou 2016; Galpin 2017; Grimmel and Giang 2017). The (re)creation of interior frontiers thereby mark a transition from a 'summer of welcome' in 2015 in the public perception to a bitter political conflict between EU member states in the migration issue that affects notions of civic solidarity (Sandberg 2019).

This article explores the call for solidarity in the EU from the perspective of constructing a common cultural heritage of the Union and stems from the notion of solidarity embedded in European heritage as discussed by Delanty $(2017,2018)$. Our aim is to develop this statement further on both a conceptual as well as an empirical level by focusing on the interrelationship between heritage and solidarity in the context of the EU. On the one hand, it is a political choice to make historical events and occasions of solidarity as part of European heritage. On the other hand, heritage is used for evoking solidarity and a sense of belonging in the EU among contemporary Europeans (see also Borgmann-Prebil and Ross 2010; Delanty 2017). We see these two processes as inherently political (e.g. Featherstone 2012) and approach them as politics of solidarity that endeavours to legitimise certain meanings at the expense of other possible meanings and interpretations (cf. Smith 2006, 81) without being able to guarantee that the interpretations are taken for granted. Hence, the same heritage can be used to invoke solidarity towards different people and contradictory societal developments.

We focus on the flagship EU heritage action, the European Heritage Label (EHL) established in 2011, that seeks to 'bring to life the European narrative and the history behind it' (EHL website) by selecting heritage sites according to their symbolic value for 
Europe's history and integration (EP 2011). For this article, we selected from a larger set of data two EHL heritage sites that focus explicitly on the notion of solidarity and on civic participation on national and European level: the Hambach Castle (HC) in Germany and the European Solidarity Centre (ESC) at the Historic Gdańsk Shipyard in Poland, which were both awarded the European Heritage Label in 2015. While putting the concept of solidarity in similar ways into practice through educational and cultural activities, they form fruitful data to scrutinize what can be called 'solidarity from below' (Featherstone $2012,5)$ together with its strong potential to produce societal change. Furthermore, the selection of one 'East European' heritage site focusing on the dissolution of the Communist block in the near past and one 'Western' site from the $19^{\text {th }}$ century enables us to discuss the notion of solidarity in a wider geographical and time frame beyond specific events and political regimes.

We explore the politics of solidarity at $\mathrm{HC}$ and ESC asking what elements and dimensions of solidarity are brought to the EHL by the sites and their exhibitions, how do the sites participate in forming common imaginaries of Europe and how does the transformative potential of heritagised solidarity becomes visible in contemporary EU. The article introduces first the theoretical framework and the data and methods. We elaborate solidarity and heritage as a communication process as well as the supposed transformative potential inherent to the terms. Our empirical analysis consists of the comparative analysis of the two sites. The article concludes with a discussion of the diverse use of the past in politics of solidarity in the framework of the EHL.

\section{Heritagising solidarity}

The interrelations between heritage and solidarity emerge from their shared background in modernity. As modern political communities are not seen in terms of natural creations, they bring forth the power of human agency (Delanty 2017, 179). These communities 
stem from and simultaneously form human visions, including future imaginaries of the world (ibid.). Indeed, Harrison $(2013,4)$ states that heritage emerges first and foremost from the relationship between people, objects, places and practices and is about the people's 'relationship with the present and the future' (see also MacDonald 2012). By the same token, issues related to solidarity may raise questions about who and, above all, on what basis people belong to political communities (Delanty 2017, 179). Although common experiences are likely to diminish in contemporary modern societies, communicative links between people make a shared world possible. This makes communication crucial in the legitimation and integration processes of complex modern societies (Graham and Howard 2008, 1-3; Delanty 2017, 183-184).

On the basis of the above, we focus on two interrelated aspects of heritage and solidarity, namely communication and its transformative potential. We explore heritage in terms of politics of solidarity, which includes paying attention to bottom-up communication processes and both bottom-up and top-down endeavours to evoke and develop solidarity. In line with critical heritage studies, we understand heritage as a process of communication that may enable us to expose dissonances, and facilitate societal dialogue and public engagement (Peckham 2003; Harrison 2013; Kisić 2017). According to this understanding, heritage at its best is a polyvocal communication among many actors entangled with the notion of solidarity needed for societal inclusivity, cohesion and a sense of a shared world (Delanty 2017, 178; see also Dicks 2000; Groote and Haartsen 2008). However, in practice, heritage works often as an 'authorised heritage discourse' (Smith 2006, 12). Smith coined this term to show the widespread understanding of heritage in terms of a fragile phenomenon that should be safeguarded and saved for future generations by experts. As an authorised phenomenon, heritage tends to be one-dimensional and often monovocal with few speakers, supposedly heritage 
practitioners and other experts, and many recipients (Smith 2006, 37; see also KaasikKrogerus 2019, 5-6, 12).

The characteristics common to both poly- and monovocal communication are the importance of interpretation and participation, since people make diverse and contradictory interpretations of the narratives conducted by the heritage sites on the basis of their personal, political, cultural and societal background (Breglia 2006, 12; see also Dicks 2000). The dissonance of meaning-making shows how the production and use of heritage takes place in social interactions among people, including heritage practitioners, stakeholders and citizens (Graham and Howard 2008, 2; see also Breglia 2006, 14). Such processes, even if not dialogic, have the capability to evoke solidarity, that by generating and shaping values and identifications (Featherstone 2012) makes possible the trajectory towards a 'shared world'.

Solidarity is continuously created, maintained and contended in social, political and communicative fields (see also Featherstone 2012; Grimmel and Giang 2017, 2 ) as a process that invokes a specific 'we-thinking' and a sense of social and political identification and belonging (see also Laitinen and Pessi 2014, 10-11. Italics in the original). Unsurprisingly, such a process may also lead towards an ambivalent societal engagement of citizens instead of strengthening a sense of belonging and shared world (cf. Breglia 2006, 14). By understanding solidarity both as having a societal impact and being a consequence of communication processes, this leads us towards our second point, the transformative potential of heritage and solidarity. The transformative potential of solidarity is largely based on its practical dispositions to act and show support (Laitinen and Pessi 2014, 11) as well as its ability to construct, cement and challenge relations between people and places (Featherstone 2012; see also Kapeller and Wolkenstein 2013). 
Hence, the notion of solidarity includes both a potential to maintain and to challenge, the status quo. The same potential that makes possible but does not guarantee societal change or transformation, is also characteristic to heritage. We understand heritage as an ongoing social, political, discursive process utilising the past with the aim to influence the future imaginaries, created and shaped by various actors according to political, economic and social interests (Graham and Howard 2008, 2; Harrison 2013, 4; Delanty 2017, 4). In this process, sites, objects and values 'become' heritage and gain shared meanings within a specific social context (Lähdesmäki 2014). Thus, contested and contradictory uses of the past in this meaning-making process make heritage inherently dissonant (Kisić 2017). As both a source and a result of social conflict, inclusion, and exclusion (Smith 2006; Graham and Howard 2008, 3; Harrison 2013), heritage becomes feasible in evoking, spreading and challenging solidarity. However, as our analysis will show, it cannot be taken for granted that solidarity in Europe is necessarily a 'positive' condition leading to expected transformations, since it can also be invoked against the EU (cf. Delanty 2017, 178, 186).

\section{Data and Methods}

The EHL report pointed out the European significance of the Hambach Festival in 1832 as a symbol of the struggle for civil liberties and its historic role in the development of civic movements demanding liberal values and democracy in Germany and in Europe (EC 2014). The Hambach Festival was an inherently political event in disguise of a popular festival, at which approximately 30.000 people from various German regions and abroad came together to protest against political and economic oppression and called for liberal and civic rights. The site of Hambach Castle later became known as the 'cradle of German democracy'. 
The Gdańsk Historic Shipyard consists of four parts including the European Solidarity Centre, negotiations hall (BHP Hall), the historic Gate No. 2, and the Memorial to the Fallen Shipyard Workers of 1970 together with the Commemorative Wall at Solidarity Square. The site was awarded the Label in recognition of the fundamental influence, which the events in the 1980 s organised by the Solidarity movement (Solidarność) in the shipyard in Poland had on the process of political struggles in Central and East European (CEE) countries that culminated in the collapse of the Soviet Union in 1991 and the end of the Cold War (EC 2014).

While the two heritage sites mediate events and processes from different historical periods, both connect to the narrative of solidarity through a variety of events, phenomena and actors, which are employed for constructing future imaginaries of belonging either in terms of a single distant past event (HC) or as a decades-long process from a recent past (ESC). Furthermore, these sites were selected because they both engage in politics in their exhibitions as well as in their daily practices, which allow for a more versatile analysis of the politics of solidarity.

The article is based on fieldwork data gathered at the two heritage sites in August (HC) and September (ESC) 2017 as part of a broader research at eleven EHL sites in Austria, Belgium, Estonia, France, Germany, Hungary, Italy, Poland, Portugal and the Netherlands. The scale of this research project requires 'team ethnography', in terms of using collaborative approaches for conducting fieldwork in multiple locales and coproducing knowledge at manifold levels. The fieldwork was divided among members of the research project, and therefore one of the authors conducted fieldwork at ESC, while the other visited HC (for more details on our approach, see Lähdesmäki et al. forthcoming). 
The data includes semi-structured interviews with visitors and heritage practitioners, observation of the sites and their exhibitions, and diverse text materials such as catalogues, websites and promotional and educational material. This article focuses primarily on the permanent exhibitions of the two selected sites and the interviews conducted with practitioners $(\mathrm{N}=6)$ as well as visitors $(\mathrm{N}=49)$, and uses the sites' websites and promotional materials as a background data. The interviews were conducted either individually or in small groups of two to three visitors of the heritage site, whereas all practitioner interviews were conducted individually. The visitors were aged between 18 and above 80 years and had a broad educational background ranging from high school diplomas to higher university degrees. The interview questions concerned the visit experience and European cultural heritage but did not ask questions explicitly related to solidarity. The interviews were transcribed and, if necessary, translated into English.

Our analysis was done in two phases. First, each author processed the data from 'her' site through close reading of the transcriptions, promotional and educational materials as well as by coding explicit and implicit references to solidarity and related issues. In the second phase, the pre-analysed data was brought together and jointly analysed with a special emphasis on communication and transformation. Our analysis showed that the heritage sites engaged with the notion of solidarity in two analytically separate ways, one concerned its representation at the exhibitions and the other aimed at evoking a sense of solidarity in practice by engaging with the audience through projects and events. This enabled us to formulate two distinct categories of the politics of solidarity: 'communicating solidarity', with a focus on narratives, and 'evoking solidarity', with a focus on engagement and interpretation. In the next section, we scrutinise how the idea of solidarity is set into European heritage and used for evoking the solidarity of Europeans at Hambach Castle and the European Solidarity Centre. 


\section{Politics of solidarity at Hambach Castle and the European Solidarity Centre}

Hambach Castle's permanent exhibition about Hambach Festival was opened in 2007 and is displayed in two rooms on the top floor. The exhibition has five thematic parts, all of them related to societal transformation. In the first room there are (1) the historical context and planning of the Hambach Festival, including (2) the colours of black-red-gold as German symbols of unity and freedom and the presentation of (3) freedom of expression and censorship after 1832 and in the following 150 years. In the second room, the themes are (4) the emerging liberal and national movements calling for a constitution and parliament as well as the women's rights movement in 19th century Germany, and (5) the exhibition ends with situating the demands of Hambach Festival in the quest for 'Fundamental Rights, Freedom and Peace', both in a German and wider European context.

The permanent exhibition of the ESC consists of seven themed rooms and starts from contextualising the conditions at the Gdańsk shipyard during the period of Communist Poland and introduces the spreading of the Solidarity movement across Polish society. One of the rooms is dedicated to the establishment of martial law (from December 1981 until July 1983). This is followed by rooms that relate to the emergence of round-table negotiations between the Communist authorities and the Solidarity movement and the first partly free elections in the Soviet Bloc (1989). The narrative is finalised with the collapse of the Soviet Bloc and the last room of the exhibition, 'A Culture of Peaceful Change', is dedicated to the general power of peaceful negotiations to contribute to great societal changes.

The following sections of empirical analysis scrutinise the politics of solidarity on the basis of the narratives of the sites, as well as the communication of their messages and interpretations in audience engagement. We start from how solidarity is 
communicated on the EHL sites as a bottom-up process with a potential for change and then move on to explore practices of evoking solidarity and related consequences.

\section{Communicating solidarity as a bottom-up transnational process}

The permanent exhibitions of both the Hambach Castle and the European Solidarity Centre illustrate well, what the notion of 'unity in diversity' implies. Both sites mediate this idea by stressing the significance of bottom-up participation in producing social and political change. The HC exhibition communicates to the visitor the insight that by the standards of the time, the organisers of the Hambach Festival managed to reach an outstanding number of people; approximately 30,000 participants attended the event from various regions across Germany, as well as from France and Poland. Despite the framing of the event in a German historical context, the exhibition stresses the shared experiences that connected people across social classes, educational backgrounds and ages as well as united men and women in their demands for national unity, social equality and a broad European solidarity for the struggle of freedom (Stiftung Hambacher Schloss 2013).

\section{[Figure 1 near here]}

The creation of a new sense of societal and civic solidarity provides a thread that helps to situate the visitor in the historical timeline of the events and familiarize them with society's transformation. At the same time, it also tells visitors that people in the past century were strongly moved by questions of social justice, and shared modern ideas that promoted popular sovereignty, equality, tolerance, democracy, freedom of press and assembly and liberal economy.

Likewise, the permanent exhibition of the ESC communicates the notion of solidarity to the visitors as a bottom-up process that has a strong potential to produce change. The exhibition starts with evoking the working and social conditions in the shipyard milieu at the turn of the 1970s and in 1980, and displays the workers' 
dissatisfaction with these. The first room is mostly dedicated to the strike at the Gdańsk Lenin Shipyard in August 1980, which is seen as a success. The strikes spread across Poland and at their peak, workers of about 800 enterprises expressed solidarity with the strikers. The ESC shows the events leading to the Gdańsk Agreement on 31 August 1980 that provided a guarantee that the economic and social demands of the workers would be met. The processes enabled the creation of a new social organisation known as the Independent Self-Governing Trade Union Solidarity (Solidarność).

\section{[Figure 2 near here]}

The exhibition shows that local people from Gdańsk and well-known Polish public figures united in a gesture of solidarity to support the political and social objectives of the strike. The involvement of intellectuals and prominent representatives of the world of science, culture and art as well as the support of the Catholic Church played key roles in the collaborative aspect of the strike to bring about change. Collaboration was required between a variety of communities, so that the large scale protest against authorities provided 'a sense of unity and strength' between the strikers and their supporters.

In the context of participation in the respective events, the two EHL sites emphasise the strong transnational and cross-border aspects. The exhibition shows how at its peak, Solidarność had a strong national, regional and international impetus and the bottom-up actions gained a lot of publicity both in Poland and abroad. Also the HC exhibition stresses the peaceful pan-European character of the festival with participants showing support for the Polish struggle for independence from Russian domination and for key ideals of the French Revolution by carrying Polish flags and the French tricolor during the event. To communicate the narrative, the $\mathrm{HC}$ exhibition invites visitors to sit under over-size hats and listen to selected speeches of German, French and Polish speakers who demanded political freedoms, asked for a united Germany and a 
'confederated states of Europe', or called for political and social equality between men and women during the Hambach Festival.

\section{[Figure 3 near here]}

The exhibition increases the understanding of the event in a broader historical, transnational and European context. Thus, the HC exhibition forges a bridge between the events of 1832 and the German constitution of 1949, which adopted crucial demands of the Hambach Festival. The exhibition refers to the demands' universal significance for the adoption of democracy in Europe and the creation of the EU. Similarly, the exhibition of the ESC ends by showing human rights 'carved into stone' in 193 languages, which suggests the triumph of these values in Europe.

However, the two sites vary in mediating solidarity as a process. The ESC communicates solidarity as both the Solidarność movement as well as the process of solidarity in terms of long-term scale, whereas the Hambach Festival is presented as a one-time event putting solidarity into practice. The ESC shows how solidarity spreads from the shipyard to other Polish enterprises, the intelligentsia and abroad (e.g. authorities, media, trade unions, citizens). The HC exhibit suggests the gathering of 1832 did not profess to wanting to have any immediate political effect but did lead to the implementation of restrictive politics and increased surveillance and censorship, which forced many leading German intellectuals to emigrate or to retire to a non-political life. Furthermore, national interests soon complicated the public display of transnational solidarity in the struggle for a common cause. However, the $\mathrm{HC}$ exhibition stresses the importance of the event as the first public call for Civic rights and freedoms uniting a large heterogeneous crowd of common people, which is shown to have impacted on the German constitutions of 1848, 1918 and 1949 and Germany's post-1918 democratic history. While the HC exhibition predominantly discusses the significance of the event 
for advancing democracy in a German historical context, it also offers a broader context for interpreting the past, which communicates to visitors the understanding that certain principles, such as solidarity, freedom of expression, human rights and democracy are precious and desirable objectives.

The ESC narrative contains a similar political backlash, since the initial success and enormous growth of the Solidarnos'ć movement was followed by the state's imposition of martial law. From the perspective of solidarity, this approximately two years period (1981-1983) of harsh societal conditions and authorised violence clearly encapsulated the trend that lasted since the late 1940s: the continuous mundane bottomup solidarity of the citizens entangled with the failure of the Communist state authorities to evoke a notion of solidarity among the 'working people', as indicated by the official rhetoric. The exhibition points out that the official declarative slogans were vague and disconnected from people's daily reality. The display communicates how people responded to this with an increased sense of solidarity targeted against the regime by using popular culture, humour and irony. Rather than escapism from the official reality as was the case in Germany in the aftermath of the Hambach Festival, the issue at the ESC is about imagining a different societal order via active doing and performing (cf. Delanty 2017; Smith 2006). The failure of the Polish authorities shows how societal change is possible only if solidarity is evoked on a daily basis, and is constituted by shared experiences and practices.

\section{Evoking solidarity}

The notion of daily practice gives a good perspective for analysing the process of forming and evoking solidarity on the basis of a close and more distant past. As examples of the EHL politics of solidarity, Hambach Castle and European Solidarity Centre mediate to the visitors an understanding of the importance of solidarity. While the ESC focuses on 
the memory of (everyday) solidarity in Poland in the 1970s and 1980s that led to societal transformations, the $\mathrm{HC}$, because of the greater distance into the past, offers a view on solidarity in terms of a universal value or a desirable (future) achievement. Visitors to HC need to rely on a more distant and abstract interpretation of the historical past. By contrast, the ESC draws on personal memories of still living people. Indeed, several visitors at the ESC explained that they still remembered the events of the 1970s and 1980s, while others had heard about 'those times' of Poland's communist past and the events at the shipyard through their parents, grandparents or other people whose personal accounts helped them to relate to past experiences.

As our research interviews indicate, visitors at both sites engaged with the narratives of the sites. Several visitors at both HC and ESC spoke of gratefulness and respect towards the accomplishments of previous generations and stressed equal importance of the need for children and young people to learn about past events and to remember and relate to the story of struggle over freedoms and rights. At the same time, our analysis also shows differences between the transmissions of the distant and near past to the visitors. On the one hand, it is easier to evoke affective or emotional closeness to the experience that happened in the recent past than in more distant history. On the other, in the case of the recent past, there is a stronger possibility that the experience gets 'spoilt' by contemporary reality.

Based on the mediated insights into the experiences of the people in the 19th century, visitors to $\mathrm{HC}$ often conclude that people now and in the past shared similar aspirations for ensuring a better life. This notion of 'intergenerational solidarity' serves to confirm specific values, such as human rights, democracy or rule of law as part of a universal moral concept, which the visitors view as fundamental for modern societies. The exhibition's examples of violations of the freedom of press in 20th century Germany 
(including examples from Nazi-Germany, the German Democratic Republic and the Federal Republic of Germany) contribute to this idealised view and trigger associations of modern dangers to democracy processes within and outside Europe. In some cases, this lead $\mathrm{HC}$ visitors to express a sense of transnational solidarity towards people who today are (still) denied their fundamental rights and freedoms. Such recent contextualisation and comparison of historical experiences enables visitors to identify possible setbacks in contemporary societies and, in addition, to firmly establish a link between the notion of solidarity in the past and present days and connect to contemporary value discourses.

The HC offers various educational workshops and cultural activities aimed at raising awareness about the interrelation between the freedom of speech and democracy, and to sensitize in particular young people to the importance of press freedom in the times of 'fake news'. Another focus is on increasing knowledge about the meaning and role of solidarity for producing social cohesion in contemporary times, with a special emphasis on Europe. One of the workshops, called House of Europe, is designed to encourage both a critical view on present-time Europe and the development of a vision for Europe among young people, as the site practitioners explain. In addition, $\mathrm{HC}$ offers a diverse cultural program and infotainment, including the popular 'Democracy Forum' and the 'Hambach Discussion'. According to the site's manager, both fora provide a stage for constructive discussion and exchange on topical political, social and cultural issues between representatives from different areas of society, politics, media and culture.

The ESC clearly emphasises a rupture between the communist era and the years after the collapse of the Communist Bloc. The victory of the Solidarity movement in the elections of 1989 meant the official defeat of the Polish Communist party, a process, as 
the electronic map in the ESC shows, which spread to other Soviet Bloc countries and eventually led to the collapse of the Bloc.

\section{[Figure 4 near here]}

After the triumph of the Solidarność movement in the 1989 elections, many former political activists of the movement continued to be public figures and important political decision-makers in Poland, and their names, faces, and voices are still present in the public sphere (Pearce 2009, 159). However, as site representatives related in the research interviews, recent political contradictions and societal divisions make it rather difficult to present the legacy of the Solidarity movement, since former allies might be current foes and therefore unwilling to perform together in 'a common story'. In this context, the ESC aims to act as both a cultural institution and a public place open for people across different age groups and educational levels for strengthening societal dialogue as well as social cohesion and Polish civic culture, as one site representative puts it. For this purpose, the center organizes various educational and cultural activities for children and young people (e.g. art workshop With Youth and Solidarity) that aim to empower young people to take action by mediating a sense for values, such as freedom, solidarity and respect for diversity (ESC website). In addition, the center's cultural activities for the local population include diverse social, cultural and educational projects and a Film festival in the framework of the European Forum programme that is dedicated to films, music and debates about issues like freedom and democracy (interviews, ESC website).

\section{Discussion: divergent interpretations and practices}

The two sites share an emphasis on using educative approaches for communicating a sense of solidarity through the everyday operational work at the sites. The politics of solidarity at these EHL sites is constituted by exhibitions and manifold activities, in which 
the significance of constitutional and liberal values, rights and freedoms on the one hand or the ideas of participation and peaceful negotiations on the other, figure as main messages for the visitors to be taken home.

The main narrative at Hambach Castle emphasises the significance of the wider public participation in events of 1832 for the development of a German democratic and constitutional movement. As one heritage professional working at the $\mathrm{HC}$ explains, despite the time gap of two centuries, the castle still tries to 'act in the spirit of the Hambach Festival'. Apart from organising various workshops, the site cooperates in local community projects. For instance, one of such projects is a specific integration project conducted together with the nearby town of Neustadt, the local Community College and the memorial site for the victims of National Socialism (NS), which aims to familiarise young refugees with issues of freedom, democracy and civic solidarity in the context of German history. The project 'Gute Zeiten - Schlechte Zeiten' (good times - bad times), which alludes to the name of a popular German mainstream series that has been running since 1992, uses the example of Hambach Festival for raising awareness of the 'good times', the positive aspects of democracy and solidarity, whereas the NS dictatorship serves as a direct example for the negative times. The encounters between young refugees and the local youth within the project foster reflection and encourage the exchange of views and positions (interviews, $\mathrm{HC}$ ).

In a similar vein, the ESC promotes dialogue between various groups in society in the framework of its educational programs and deals with questions of social inequality, poverty and multiculturalism in public discussions. For instance, one project called 'Try to understand August' seeks to stimulate dialogue across the polarized Polish society by alluding to the negotiations during the strike at the shipyard in August 1980 and emphasising the power of non-violent and peaceful negotiations as a universal 
mechanism applicable also in the current political context. Another project aims to facilitate contact between the local population and non-natives, such as a project that involves Polish school pupils on the one hand and Muslim migrants and refugees from Chechnya and Syria on the other. The ESC also cooperates with the city of Gdańsk by organising a culture club for immigrants with the objective to make them 'feel better in our city', according to one practitioner (interviews, ESC).

The two sites offer more than one interpretation of heritage to the visitors. As our analysis shows, the question of 'what is the spirit of the heritage' might result in contradictory meaning-making processes, which in extreme cases can juxtapose the messages of the site's narratives. For instance, the interviews conducted at the ESC show how the message of the site can be interpreted from two different perspectives. The practitioners emphasised the importance of negotiations as a universal method applicable in the $21^{\text {st }}$ century. The exhibition additionally constructs a rupture between the past oppressive regime (an 'enemy' which was defeated) and the 'new era' that started with a collapse of the Communist Bloc, while the final room of the exhibition continues to emphasise the validity of the seeking for peaceful solutions. However, despite the rupture between the communist past and the achieved freedom, as indicated by the exhibition, resisting oppression and fighting for freedom is also a universal story, not something specific for transforming Poland and Eastern Europe in the 1980s.

Our visitor interviews exemplified heritage as 'an experience or moment of active cultural engagement' that can have various consequences (Smith 2015, 460). Instead of (or in addition to) the European Solidarity Centre's message of participation and nonviolent negotiations mediated by the exhibition and activities, visitors may remember the importance of fighting against potential enemies and oppressors. In this manner, the idea of solidarity could be rhetorically constructed in terms of a unifying notion but also in 
terms of blaming and excluding internal and/or external 'enemies' (cf. Karaliova 2016, $145,157)$. Hence, solidarity as heritage is neither 'good' nor 'bad' but might have various connotations and consequences in various contexts. In the current societal context of Poland where the state authorities criticise the ESC for being too 'European' and insufficiently 'Polish', the interpretation can ironically turn against the EU as a new 'oppressor' of Poland. The site tries to equilibrate a biased interpretation of solidarity only in the exclusive context of national struggle for freedom by offering its site as a venue or an 'agora', open to everybody, where people with divergent opinions can come together and discuss their views, thereby encouraging civic participation and exchange.

The case of HC shows how different interpretations can turn upside down the message of heritage narratives and be used against the approach communicated by the site. Simultaneously it gives a good example of heritage in terms of participation where various groups consider the site itself to be valuable in the process of strengthening their sense of belonging. Every year, Hambach Castle organises a large commemoration of the Hambach Festival around the date of the original event (27 May). In past years, the staff has observed the arrival of small groups of individuals, who silently demonstrate against the legitimacy of the German state and sometimes show the German tricolor turned upside-down as a form of visual protest. These individuals are members of a very heterogeneous but increasingly radicalising movement, known as Reichsbürger, which is estimated to number approximately 10,000 people. The self-proclaimed citizens of the German Empire within the borders of 1937 are united in their resistance against modern societies, and in their ideas of global conspiracy and foreign rule over Germans, which is intertwined with abstract and concrete enemy images, such as the EU, USA or a Zionist world conspiracy (Oltermann 2016). Moreover, HC was used in recent years as a symbolic venue for assembling heterogeneous groups from the right, who range from the 
very conservative to the far-right spectrum, for voicing their discontent with the politics of the German government and their anti-EU views, including the German right-wing party (Alternative für Deutschland) (Höll 2018).

The presence of the Wutbürger (enraged citizens) and Reichsbürger as well as the political instrumentalisation of heritage in terms of a 'social glue' (Niklasson and Hølleland 2018, 126) by populistic national and far right groups put values of democracy and solidarity on test at $\mathrm{HC}$ (interviews with practitioners, HC). The ideological rhetoric shared by the diverse right-wing spectrums across Europe show that the concept of heritage as 'social glue' is directed towards the rigid maintenance of an alleged status quo and the promotion of whatever serves to strengthen a predetermined national character (Niklasson and Hølleland 2018, 136). In their case, solidarity is primary understood to extend to their 'own people', which cultivates an exclusive, ethnic, national and racist idea of solidarity based on 'blood-and-roots-genealogy' that is at odds with the broader understanding of solidarity promoted by $\mathrm{HC}$ as a factor for advancing integration and tolerance towards others (interviews with practitioners, $\mathrm{HC}$ ).

Although HC clearly distances itself from the views and sentiments of the diverse protest groups coming to its premises, the management regards it as their duty to act in the spirit of 1832 and to allow the freedom of expression and presence of such groups. The view of one site practitioner is that democracy needs to endure their presence, as they are nevertheless 'part of society' who 'bring in their own point of view', which is shared by another colleague who stresses the symbolic significance of Hambach Castle, which 'after all [is] a place of free speech' (interviews, HC). Thus, heritage practitioners working at $\mathrm{HC}$ interpret solidarity in terms of an inclusive force that has the capacity to unite all parts of society, if not in meaning-making then in participation. In the case of $\mathrm{HC}$, freedom of expression is understood as one of the most important pillars of 
democratic societies, which is inextricably linked with the experience of various 'dark' periods in modern German history and democratisation efforts after 1945.

\section{Conclusions}

The production and meaning-making of heritage can be understood in terms of various communication processes that take place between a variety of actors (professionals, visitors, wider society), and the diverse and even contradictory interpretations can have wider societal implications, as our analysis shows. Both EHL sites in this study emphasise the transformative capacity of solidarity and use it for forming common imaginaries of Europe that are related to the notions like human dignity, hospitality, human rights, democracy and peace (see also McDowell 2008, 48; Delanty 2017, 21). Imaginaries of a community's future are associated with sharing commonalities for providing solidarity and social cohesion.

We argue that instead of dealing with the maintenance and transformation of European societies as either-or processes, the EHL provides a good example of their interrelations. Solidarity and heritage are part of the EU (cultural) policy to manage the crises of legitimation and to maintain the continuity of the Union. At the same time, the EHL is an example of the continuous (trans)formation of European heritage and therefore also of the EU. By designating the Label to those sites associated with the idea of solidarity, certain aspects are excluded, while others are adopted or 'naturalised' as part of 'European heritage' in this politics of solidarity. However, this official position is challenged by the affectivity of heritage that makes it difficult to govern it 'from above' (Smith 2004; see also Lähdesmäki 2014).

The capability of communicating and evoking solidarity at the heritage sites is interrelated with the role of social actors for constructing the past in various processes. The experiences of the past contribute to determine our understanding and interpretation 
of solidarity in the everyday. While Delanty (2017) emphasises the importance of political solidarity as part of European heritage, the EHL sites endeavour to evoke solidarity. The stories and narratives about 'common people' and their everyday (struggles), both told by the people and created by the sites, become part of the official European heritage, showing that bottom-up practices may change world trajectories. While heritage sites seek to facilitate the simultaneous maintenance and transformation of heritage by invoking shared experiences in the everyday towards various groups of people and in diverse historical, social and political contexts, they also help negotiating abstract meanings of solidarity (in terms of a universal value; part of a shared European heritage) in the interaction with the wider public. At the same time, heritage as a token of solidarity is also evoked in discussion about migration, Brexit, or the future of the EU, making both heritage sites connect to topical debates and become actors of solidarity in a contemporary context.

The politics of solidarity at these two EHL sites is broad. Both sites create (sometimes implicit) positive associations with Europe. On one hand, they show how abstract objectives of democracy, rights and freedoms are intertwined with personal experiences and social, political and economic concerns of the everyday. On the other hand, such abstract objectives also connect to a transnational heritage that can articulate solidarity, identity and values in relation to the past across national divides and different traditions and memories. Thus, ESC and HC contribute to form solidarity as part of European heritage that puts the emphasis on the transnational dimension of heritage and the interconnection of histories. Attempts to evoke solidarity towards abstract moral and universal values or a social entity (nation-state or EU) show that such concepts are not fixed, and therefore the meanings and connections in terms of inclusion or exclusion can also vary a great deal. 
At the same time, the exhibitions show the limitations of 'heritagising' solidarity, since the diverse use of the past in the politics of solidarity can be used for creating contrary goals: social cohesion as well exclusion. Heritage is often connected with a notion based on ethno-nationalist belonging, and less linked to civic solidarity (Delanty 2017, 134-135; Niklasson 2017). Our article shows that civic solidarity does not overcome differences but enables plural interpretations of the past, as solidarity can be employed in an intolerant or authoritarian way that rests on an exclusive perception of community and may create a danger for democracy from within democracy (see also Delanty 2017).

The idea of solidarity promoting a sense of 'unity' can be used as a tool for disposing of variety and silencing competing opinions. As the case studies show, the political instrumentalisation of heritage can create concrete challenges for EHL sites and links to the question of whose heritage it is and who participates in producing, forming and determining the meaning of the past. Thus, the mediation of antagonistic aspects also implies the negotiation of boundaries of what is and is not acceptable in the broader national or EU framework. Emphasising solidarity as European heritage is a political choice of the EU and the EHL sites contribute to create the success story of the EU, which can however be interpreted from different perspectives. In the most paradoxical cases, solidarity can actually be used against the EU by not challenging European heritage but by challenging the EU as the concrete phenomenon of 'Europe'.

In the current political context where powerful actors, such as far-right parties attempt to 'own' European cultural heritage and to define it from their perspective, the EHL and its sites can contribute to the debates over the meanings of solidarity as well as the scope of solidarity concerning different communities. These debates raise important questions, such as, what are the main values, how are they understood and towards whom 
is solidarity expressed? From the perspective of diverse groups of people living in Europe, it makes a difference if they experience solidarity expressed towards them or if they can engage with the endeavours of the heritage sites and feel that European heritage also tells 'their stories'.

Acknowledgement

This work was supported by the European Research Council (ERC) under the EU's Horizon 2020 Research and Innovation Program (Grant No. 636177, EUROHERIT).

Declaration of Interests

No potential conflict of interest are reported by the authors.

Sources:

Interviews with manager and heritage practitioner $(\mathrm{N}=2), \mathrm{HC}$, autumn 2017.

Interviews with manager and heritage practitioner (N=4), ESC, autumn 2017.

Interviews with visitors, $\mathrm{HC}(\mathrm{N}=24)$ and $\operatorname{ESC}(\mathrm{N}=25)$, autumn 2017.

EHL website. Accessed 28 September 2018. https://ec.europa.eu/programmes/creativeeurope/actions/heritage-label_en.

European Solidarity Centre website. Accessed 24 May 2019. http:// www.ecs.gda.pl/title,Jezyk,pid,2,lang,2.html

\section{References:}

Bell, Mark. 2010. "Irregular Migrants: Beyond the Limits of Solidarity?” In Promoting Solidarity in the European Union, edited by Yuri Borgmann-Prebil, and Malcolm Ross, 151-165. Oxford: Oxford University Press.

Borgmann-Prebil, Yuri and Malcolm Ross. 2010. "Promoting European Solidarity: Between Rhetoric and Reality?" In Promoting Solidarity in the European Union, edited by Yuri Borgmann-Prebil and Malcolm Ross, 1-22. Oxford: Oxford University Press. 
Breglia, Lisa. 2006. Monumental Ambivalence: The Politics of Heritage. Austin: University of Texas Press.

Delanty, Gerard. 2017. The European Heritage. A Critical Re-Interpretation. London, NY: Routledge.

Delanty, Gerald. 2018. "What Unites Europe and What Divides It? Solidarity and the European Heritage Reconsidered.” Asian Journal of German and European Studies 3 (3). doi: 10.1186/s40856-018-0025-x.

Dicks, Bella. 2000. "Encoding and Decoding the People: Circuits of Communication at a Local Heritage Museum.” European Journal of Communication 15 (1): 61-78. doi: $10.1177 / 0267323100015001003$

EC. 2014. European Heritage Label. 2014 Panel Report. Brussels: European Commission.

EP. 2011. "Decision No 1194/2011/EU of the European Parliament and of the Council of 16 November 2011 establishing a European Union action for the European Heritage Label." Official Journal of the European Union L 303, 1-9.

Featherstone, David. 2012. Solidarity: Hidden Histories and Geographies of Internationalism. London: Zed Books.

Galpin, Charlotte. 2017. The Euro Crisis and European Identities. Political and Media Discourse in Germany, Ireland and Poland. Basingstoke: Palgrave Macmillan.

Góra, Magdalena. 2018. "European Solidarity from the Central European Perspective." In Understanding Central Europe, edited by Marcin Moskalewicz, and Wojciech Przybylski, 453-460. Oxford: Routledge.

Graham, Brian, and Peter, Howard. 2008. "Heritage and Identity." In The Ashgate Research Companion to Heritage and Identity, edited by Brian Graham, and Peter Howards, 1-15. Aldershot and Burlington: Ashgate.

Grimmel, Andreas, and Susanne My Giang, eds. 2017. Solidarity in the European Union. A Fundamental Value in Crisis. Berlin: Springer.

Groote, Peter, and Tialda Haartsen. 2008. "The Communication of Heritage: Creating Place Identities." In The Ashgate Research Companion to Heritage and Identity, 
edited by Brian Graham, and Peter Howards, 181-194. Aldershot \& Burlington: Ashgate.

Harrison, Rodney. 2013. Heritage: Critical Approaches. New York: Routledge.

Höll, Susanne. 2018. "Hambacher Last." Süddeutsche Zeitung, May 2. http://sz.de/1.3962859

Kaasik-Krogerus, Sigrid. 2019. "Identity politics of the promotional videos of the European Heritage Label." Contemporary Politics (online). doi: $10.1080 / 13569775.2019 .1611207$

Kapeller, Jakob, and Fabio Wolkenstein, Fabio. 2013. "The Grounds of Solidarity: From Liberty to Loyalty." European Journal of Social Theory 16 (4): 476-491. doi:10.1177/1368431013479689

Karageorgiou, Eleni. 2016. "Solidarity and Sharing in the Common European Asylum System: the Case of Syrian Refugees.” European Politics and Society 17 (2): 196214. doi: 10.1080/23745118.2016.1121007

Karaliova, Tatsiana. 2016. “Let Them Talk: New Year's Presidential Rhetoric in Russia, Belarus, and Poland.” Journal of Communication Inquiry 40 (2): 145-161. doi: $10.1177 / 0196859915623493$

Kisić, Višnja. 2017. Governing Heritage Dissonance. Promises and Realities of selected Cultural Policies. The Hague: European Cultural Foundation.

Laitinen, Arto, and Anne Birgitta Pessi. 2014."Solidarity: Theory and Practice. An Introduction." In Solidarity: Theory and Practice, edited by Arto Laitinen, and Anne Birgitta Pessi, 1-29. Lexington Books.

Lähdesmäki, Tuuli. 2014. “The EU’s Explicit and Implicit Heritage Politics.” European Societies 16 (3): 401-421. doi: 10.1080/14616696.2014.894547

Lähdesmäki, Tuuli, Čeginskas, Viktorija L.A., Mäkinen, Katja, Kaasik-Krogerus, Sigrid and Johanna Turunen (forthcoming). Creating and Governing Cultural Heritage in the European Union. London: Routledge. 
Macdonald, Sharon. 2012. "Presencing Europe's Past." In A Companion to the Anthropology of Europe, edited by Ullrich Kockell, Máiréad Nic Craith, and Jonas Frykman, 233-252. Oxford: Wiley-Blackwell.

McDowell, Sara. 2008. "Heritage, Memory and Identity." In The Ashgate Research Companion to Heritage and Identity, edited by Brian Graham, and Peter Howards, 37-53. Aldershot and Burlington: Ashgate.

Niklasson, Elisabeth. 2017. "The Janus-Face of European Heritage: Revisiting the Rhetoric of Europe-Making in EU Cultural Politics." Journal of Social Archaeology 17 (2): 138-162. doi: 10.1177/1469605317712122

Niklasson, Elisabeth, and Herdis Hølleland. 2018. "The Scandinavian Far-Right and the New Politicization of Heritage.” Journal of Social Archaeology 18 (2): 121-148. doi: $10.1177 / 1469605318757340$

Oltermann, Philip. 2016. "Germany Fears Radicalization of Reichsbürger Movement after Police Attacks." The Guardian, October 21. https://www.theguardian.com/world/2016/oct/21/germany-fears-radicalisationof-reichsburger-group-after-attacks-on-police

Pearce, Susan C. 2009. "The Polish Solidarity Movement in Retrospect: In Search of a Mnemonic Mirror.” International Journal of Politics, Culture, and Society 22 (2): 159-182. doi: 10.1007/s10767-009-9061-0

Peckham, Robert Shannan, ed. 2003. Rethinking Heritage. Cultures and Politics in Europe. I.B. Tauris: London, New York.

Ross, Malcolm. 2010. “A New Constitutional Paradigm for the EU?” In Promoting Solidarity in the European Union, edited by Yuri Borgmann-Prebil and Malcolm Ross, 23-45. Oxford: Oxford University Press.

Sandberg, Marie. 2019. Ethnography et al.: Doing situated collaborative research on informal networks working in support of refugees coming to Europe (keynote(February 12, 2019). Conference 'Ethnography with a Twist', Jyväskylä, Finland, February 12-14, 2019.

Smith, Laurajane. 2004. Archaeological Theory and the Politics of Cultural Heritage, London: Routledge. 
Smith, Laurajane. 2006. Uses of Heritage. London: Routledge.

Smith, Laurajane. 2015. "Theorizing Museum and Heritage Visiting." In The International Handbooks of Museum Studies: Museum Theory, edited by Kylie Message, and Andrea Witcomb, 459-484. Chichester, West Sussex: John Wiley \& Sons Ltd.

Stiftung Hambacher Schloss. 2013. Hinauf, hinauf zum Schloss! Das Hambacher Fest 1832. Das Begleitbuch zur Ausstellung im Hambacher Schloss. Hambach/Neustadt a.d. Weinstraße: Nino Druck.

Treaty Establishing a Constitution for Europe. 2004. Official Journal of the European Union C 310.

Turunen, Johanna, Čeginskas, Viktorija L.A., Kaasik Krogerus, Sigrid, Lähdesmäki, Tumli and Katja Mäkinen. forthcoming. Poly Space: Creating New Concepts through Reflexive Team Ethnography. In: Lähdesmäki, Tuuli, KoskinenKoivisto, Eerika, Čeginskas, Viktorija L.A and Koistinen, Aino-Kaisa (eds.). Challenges and Solutions in Ethnographic Research: Ethnography with a Twist. London: Routledge.

Figure captions

Figure 1. The re-enactment of the Hambach Festival with Playmobil figures stresses the festive and inclusive character of the event. (Photo: EUROHERIT)

Figure 2. This electronic map in the European Solidarity Centre shows how strikes spread all over Poland in 1980. (Photo: EUROHERIT)

Figure 3. The audio station invites visitors to listen to the reproduction of selected speeches from the Hambach Festival in 1832. (Photo: EUROHERIT)

Figure 4. The electronic map in the European Solidarity Centre shows the dissolution of the Communist Bloc from 1989 onwards. (Photo: EUROHERIT) 